DOI: 10.18276/sip.2016.45/1-07

\title{
Gabriel Główka*
}

Szkoła Główna Handlowa w Warszawie

\section{FINANSOWE DETERMINANTY BAŃKI CENOWEJ NA RYNKU MIESZKANIOWYM W POLSCE}

\section{Streszczenie}

W artykule podjęto próbę rozpoznania czynników i mechanizmu pojawienia się i narastania bańki cenowej na polskim rynku mieszkaniowym, ze szczególnym uwzględnieniem roli systemu finansowego w tym procesie. Przedstawiono w nim szczegółowe powiązania między dynamiką wzrostu cen mieszkań a stosowanymi zasadami kredytowania nieruchomości mieszkaniowych oraz skutki zmian cen mieszkań w latach 2004-2015 dla funkcjonowania rynku mieszkaniowego, sektora bankowego oraz całego systemu gospodarczego w Polsce.

Słowa kluczowe: rynek mieszkaniowy, cykl koniunkturalny, bańka cenowa, system finansowy, kredyty hipoteczne, stabilność systemowa

\section{Wstęp}

Znaczenie rynku nieruchomości mieszkaniowych we współczesnej gospodarce staje się ważną motywacją do pogłębionego poznania procesów na nim zachodzących. Podlega on wahaniom aktywności i zmianom dynamiki rozwoju, co jest zjawiskiem naturalnym w warunkach gospodarki rynkowej. Najistotniejszym przejawem cyklicznego jego rozwoju są zmiany w poziomie cen. Wahania cen na rynku nieruchomości mieszkaniowych mają istotne konsekwencje zarówno dla sposobu

\footnotetext{
* Adres e-mail: gabriel.glowka@gmail.com.
} 
jego funkcjonowania, jak i dla sektorów z nim powiązanych. Wpływają one na kondycję i stabilność sektora finansowego, wyniki finansowe dużych grup inwestorów, a w konsekwencji tego na koniunkturę w całej gospodarce.

Kryzysy na rynkach nieruchomości mieszkaniowych są ciągle mniej rozpoznane niż na przykład kryzysy walutowe czy kryzysy finansów publicznych. Dzieje się tak prawdopodobnie dlatego, że w ostatnich kilkudziesięciu latach pojawiały się one rzadziej niż kryzysy w innych obszarach gospodarki, co sprawiało, że wynikające z nich doświadczenia były w znacznym zakresie lekceważone (Guttentag, Hering, 1984). Przykładem tego są zjawiska kryzysowe na rynku nieruchomości mieszkaniowych w Stanach Zjednoczonych w latach 1976-1980 oraz 1985-1988. Szczególnie warto wskazać na ten drugi przypadek, kiedy to w wyniku nadmiernej ekspansji kredytów hipotecznych mieliśmy do czynienia z poważnym kryzysem, którego skutkiem było bankructwo praktycznie całego sektora towarzystw oszczędnościowo-pożyczkowych (savings \& loans associations - S\&L). Następnie w latach dziewięćdziesiątych bardzo podobne zjawiska kryzysowe na dużą skalę wystąpiły w krajach azjatyckich. Pomimo tych bardzo negatywnych doświadczeń praktycznie już w 2001 roku obserwowaliśmy na amerykańskim rynku nieruchomości mieszkaniowych zjawiska prowadzące do kolejnego, znacznie głębszego kryzysu, a w latach 2003-2006 ceny nieruchomości w Stanach Zjednoczonych rosły szczególnie dynamicznie. Pojawiło się przekonanie, że zakup nieruchomości mieszkaniowych jest bardzo dobrą inwestycją, co motywowało do ich nabywania nie tylko na własny użytek czy w celu długoterminowego ulokowania środków, ale również z zamiarem ich odsprzedaży, a to oznaczało występowanie zachowań o charakterze typowo spekulacyjnym. W rezultacie oddziaływania powyższych czynników, przy jednoczesnym wsparciu tych zachowań łatwo dostępnymi kredytami hipotecznymi, powstała na amerykańskim rynku nieruchomości mieszkaniowych bańka cenowa o olbrzymich rozmiarach, której pękniecie z uwagi na dużą skalę rynku mieszkaniowego Stanach Zjednoczonych i związanego z nim sektora finansowego wywołało niezwykle negatywne konsekwencje na skalę światową.

Warto zauważyć jednak, że pomimo iż skutki tego kryzysu nie zostały jeszcze do końca przezwyciężone, to w ostatnim okresie na lokalnych rynkach nieruchomości mieszkaniowych obserwujemy niepokojące zjawiska wzrostu cen sugerujące tworzenie się kolejnych baniek cenowych (Deptuła, 2013). Wynika z tego, że ciągle bardzo istotne znaczenie ma badanie przyczyn powstawania baniek cenowych na rynkach nieruchomości mieszkaniowych, gdyż wiele ich uwarunkowań i procesów prowadzących do kryzysów nie zostało jeszcze do końca wyjaśnionych. 
Niniejszy artykuł poświęcony został zbadaniu mechanizmu tworzenia się i narastania bańki cenowej na polskim rynku nieruchomości mieszkaniowych. Dynamika wzrostu cen mieszkań w Polsce w latach 2004-2008 była tak silna, że daje to podstawę do formułowania tezy o pojawieniu się bańki cenowej. Ważnym zatem zadaniem jest zbadanie uwarunkowań i mechanizmu tak dynamicznego wzrostu cen. Prawidłowe rozpoznanie tego mechanizmu jest warunkiem niezbędnym do podejmowania prób ograniczania skali tego zjawiska w przyszłości i tym samym ryzyka negatywnych skutków z nim związanych.

\section{Bańka cenowa na rynku nieruchomości mieszkaniowych w ujęciu teoretycznym}

Jedną z podstawowych przyczyn wstrząsów kryzysowych we współczesnej gospodarce są wahania cen aktywów na poszczególnych rynkach. Zasadniczym problemem dotyczącym rynków aktywów jest problem zbieżności cen aktywów $\mathrm{z}$ ich wartością fundamentalną. Narastające dysproporcje między ceną a wartością aktywów prowadzą najczęściej do pojawiania się na rynku zjawiska, które określane jest mianem bańki cenowej. Przy czym jako wartość fundamentalną danego aktywa przyjmuje się jego wartość wynikającą z użyteczności aktywa wyrażonego poziomem cen w warunkach równowagi. Bańka cenowa na rynku aktywów oznacza, co wynika z jej natury, odchylenie od stanu równowagi dynamicznej danego rynku (Kalicki, Krześniak, 2010).

Przyjęta nazwa tego zjawiska trafnie odzwierciedla nietrwałość i niestabilność obserwowanego procesu. Zdaniem Kindlebergera (1999) bańka cenowa to gwałtowny i ciągły wzrost cen aktywów, który kreuje oczekiwania dalszego ich wzrostu przyciągając tym samym nowych inwestorów. Istota bańki cenowej przejawia się zatem w zachowaniach uczestników rynków aktywów polegających na podejmowaniu transakcji aktywami przewartościowanymi. Zakup aktywów dokonywany jest często nie ze względu na oczekiwaną stopę zwrotu z danej inwestycji, ale w oczekiwaniu na to, że taki towar uda się sprzedać po wyższej cenie kolejnemu nabywcy (the great fool).

Zjawiska baniek cenowych, o różnej naturze, możemy obserwować na wielu rodzajach rynków aktywów, nie jest to zjawisko charakterystyczne tylko dla rynków finansowych. Dotyczy ono coraz częściej także rynków nieruchomości, w tym nieruchomości mieszkaniowych. W przypadku rynku mieszkaniowego możemy generalnie mówić o kilku grupach czynników, które wzajemnie się na siebie nakła- 
dając, wywołują cykle i kryzysy na tym rynku. Po pierwsze, jest to związane ze strukturalną cechą rynku nieruchomości mieszkaniowych, to jest relatywnie szybkimi zmianami popytu, które przy sztywnej i tym samym reagującej ze znacznym opóźnieniem podaży wywołują wzrost cen (Malpezzi, Wachter, 2004). To z kolei uruchamia procesy dostosowawcze na rynku, które po pewnym okresie prowadzą do wzrostu podaży mieszkań. Istotnym problemem jest jednak to, że podaż ta pojawia się z reguły wtedy, gdy popyt na rynku mieszkaniowym zaczyna gasnąć, co oznacza, że wzrost podaży często okazuje się zbyt duży. W tym przejawia się pewna specyfika mechanizmu powstawania baniek cenowych na rynku nieruchomości mieszkaniowych w stosunku do innych rodzajów rynków, jak na przykład rynku aktywów finansowych, na którym proces dostosowywania popytu i podaży jest znacznie krótszy z uwagi na możliwość w miarę szybkiej reakcji podaży tego typu aktywów. Po drugie, należy podkreślić, że podobnie jak ma to miejsce na rynku innych rodzajów aktywów, nie wszystkie wzrosty cen mieszkań mają swoją praprzyczynę w cesze strukturalnej tego rynku, muszą nieuchronnie prowadzić do głębokiego ich spadku i tym samym ryzyka destabilizacji wielu dziedzin gospodarki. Wiele zależy od wielkości pojawiającej się na rynku mieszkaniowym bańki cenowej. Bańki cenowe o mniejszych rozmiarach są z reguły w sposób stopniowy absorbowane przez realny spadek cen mieszkań, zarówno w wyniku inflacji, jak i wzrostu dochodów potencjalnych ich nabywców. Obecnie rozmiary bańki cenowej na rynku mieszkaniowym w znacznej mierze uzależnione są od tego, czy impuls wywołany czynnikami fundamentalnymi i cechą strukturalną tego rynku nie zostanie nadmiernie wzmocniony poprzez inne czynniki.

Wysoka kapitałochłonność nieruchomości mieszkaniowych wywołuje konieczność wykorzystania zewnętrznych źródeł ich finansowania. Z kolei udział kredytu bankowego w finansowaniu nieruchomości mieszkaniowych determinuje rolę sektora bankowego w kształtowaniu dynamiki tego rynku. Zmiany w kosztach uzyskania kredytu, jak również liberalizacja rynku kredytów hipotecznych mają bardzo istotny wpływ na poziom aktywności rynku nieruchomości mieszkaniowych. $Z$ reguły dochodzi wówczas do uruchomienia mechanizmu ekspansji kredytowej, co wywołuje z kolei dynamiczny wzrost cen na rynku mieszkaniowym napędzany przez tani i coraz łatwiej dostępny kredyt. Często w takiej sytuacji generowane są też błędne przesłanki do zarządzania ryzykiem kredytowym, przede wszystkim z powodu przewartościowania zabezpieczeń hipotecznych kredytów w rezultacie szybkiego wzrostu cen nieruchomości mieszkaniowych. Na rynku mieszkaniowym mamy wówczas do czynienia $\mathrm{z}$ typową inflacją o charakterze popytowym silnie 
stymulowaną przez kredyt. Uruchomione zostają tym samym, poza czynnikami fundamentalnymi, czynniki wzrostu cen o charakterze spekulacyjno-psychologicznym i popyt na rynku nieruchomości kreowany jest w znacznej mierze na podstawienie oczekiwań dalszego wzrostu cen mieszkań. Wówczas narasta z reguły bańka cenowa olbrzymich rozmiarów, którą bardzo często określa się mianem bańki spekulacyjnej ze względu na rodzaj czynników, jakie ją napędzają. Po pewnym czasie dochodzi wówczas do nieuchronnego pęknięcia bańki i mamy do czynienia z załamaniem się rynku nieruchomości mieszkaniowych, którego skutki destabilizują w pierwszej kolejności system bankowy, a następnie przenoszą się na całą gospodarkę. Trzeba pokreślić jednak, że wpływ skutków pęknięcia bańki cenowej na rynku mieszkaniowym na funkcjonowanie gospodarki może być szczególnie dotkliwy z uwagi na duży udział mieszkań w majątku gospodarstw domowych, a także istotny udział kredytów hipotecznych i instrumentów finansowych $\mathrm{z}$ nimi powiązanych $\mathrm{w}$ aktywach wielu podmiotów systemu gospodarczego. Ponadto z powodu bardzo niskiej z natury elastyczności podaży na rynku mieszkaniowym często pojawia się na nim nadmierna w stosunku do aktualnego zapotrzebowania liczba mieszkań, a ich sprzedaż zarówno przez deweloperów, jak i inwestorów jest niemożliwa, co powoduje dalsze spadki cen i rozszerzanie się negatywnych zjawisk w skali całej gospodarki.

\section{Uwarunkowania i mechanizm bańki cenowej na polskim rynku nieruchomości mieszkaniowych}

Rozwój rynku nieruchomości mieszkaniowych w Polsce w warunkach organizowania się gospodarki rynkowej w sposób nieuchronny tworzył przesłanki i warunki do pojawienia się cykliczności w jego funkcjonowaniu (Foryś, 2014). Wraz z rozszerzaniem się rynkowych zasad funkcjonowania tego segmentu gospodarki zaczęły się pojawiać okresowe wahania produkcji mieszkań i cen. Cykle te miały różny charakter i amplitudę wahań.

Ostatni cykl, który wystąpił zdaniem autora na polskim rynku nieruchomości mieszkaniowych w latach 2004-2012, miał już charakter typowo rynkowy, co wynikało ze znacznego pogłębienia i umocnienia rynkowych mechanizmów jego funkcjonowania w pierwszej dekadzie obecnego wieku. Mechanizmy rynkowe w polskim sektorze mieszkaniowym były już na tyle silne, że cykl ten miał wówczas charakter zbliżony do tych występujących na rynkach rozwiniętych. Wpływ na jego przebieg miały zarówno czynniki fundamentalne, jak i czynniki o charakterze spekulacyj- 
nym. Wskutek oddziaływania obu grup tych czynników zanotowaliśmy w Polsce gwałtowny wzrost cen mieszkań. Zjawisko to miało miejsce głównie w największych polskich miastach (zob. rys. 1). W latach 2004-2007 najwyższą dynamikę wzrostu cen obserwowaliśmy w przypadku Warszawy i Wrocławia, nieco niższy, ale również dynamiczny wzrost cen mieszkań odnotowano w Krakowie i Poznaniu.

Rysunek 1. Dynamika średniorocznych cen transakcyjnych $1 \mathrm{~m}^{2}$ mieszkań $\mathrm{w}$ wybranych miastach Polski $(\mathrm{w} \%$, rok poprzedni $=100)$

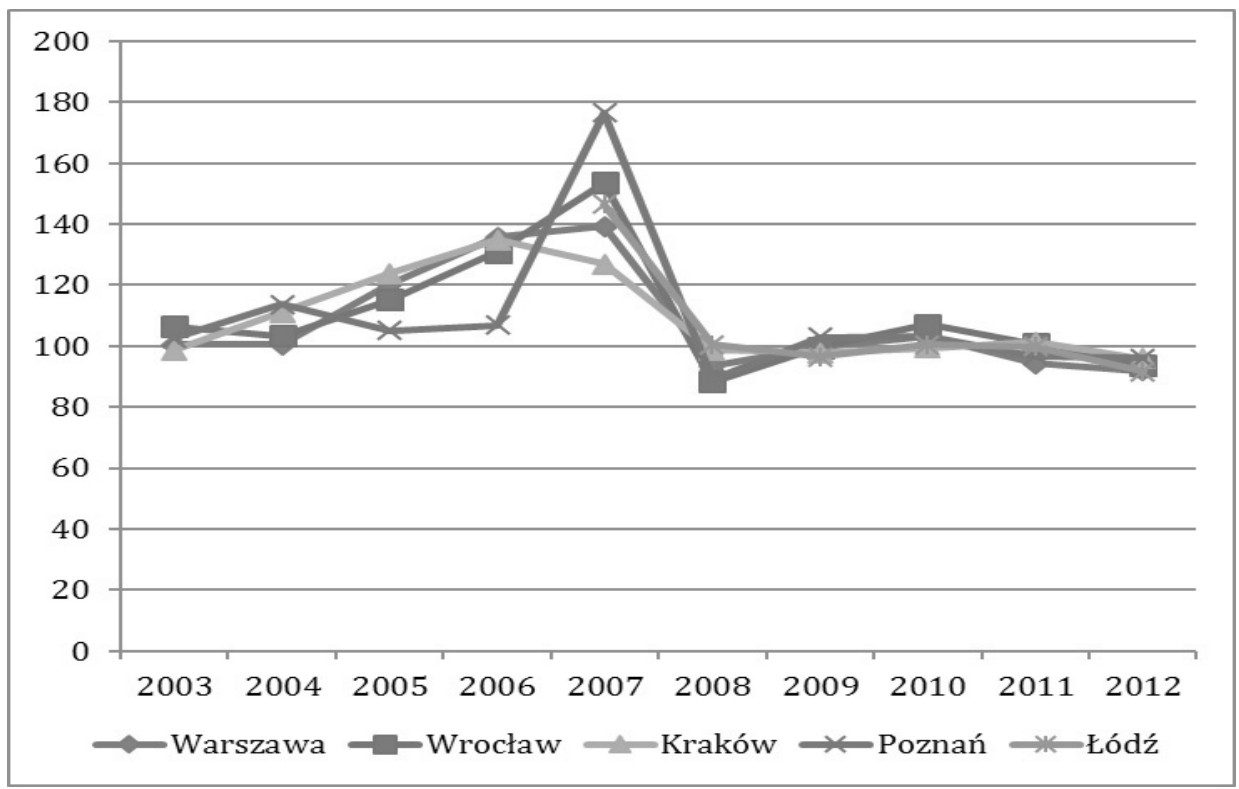

Źródło: na podstawie danych REAS, AMRON.

Analiza dynamiki polskiego rynku nieruchomości mieszkaniowych w ostatnim cyklu, czyli w latach 2004-2012, pokazuje, że w momencie rozpoczęcia badanego procesu, w latach 2003-2005, pojawił się splot czynników różnej natury, który uruchomił mechanizm wzrostu cen. Generalnie obserwowaliśmy wówczas wyraźne wzmocnienie oddziaływania czynników mających istotny wpływ na wielkość oraz zmienność popytu na rynku mieszkaniowym. W początkowej fazie badanego cyklu koniunkturalnego na popyt wpływały przede wszystkim czynniki o charakterze fundamentalnym. Podstawowym czynnikiem determinującym popyt mieszkaniowy był występujący w Polsce deficyt mieszkań i niski stopień zaspokojenia potrzeb mieszkaniowych społeczeństwa oraz związana z tym odroczona konsumpcja miesz- 
kań. Nasze zaległości w tym zakresie, jak to wynika z badań, są duże (Kucharska, Schneider, Załęczna, 2009). Świadczy o tym chociażby szacunek deficytu mieszkań w Polsce rozumiany jako różnica między liczbą zasobów mieszkaniowych a liczbą gospodarstw domowych, który wynosił wówczas około 1,14 mln mieszkań. Ponadto w badanym okresie zapotrzebowanie na mieszkania było dodatkowo wzmacniane czynnikami demograficznymi, mieliśmy bowiem wówczas do czynienia z wchodzeniem na rynek pracy i zakładaniem rodzin przez pokolenie wyżu demograficznego. Istotne znaczenie $\mathrm{w}$ tym procesie miał też przyśpieszony wzrost stopnia urbanizacji i związana z tym skala migracji do największych polskich miast. Zjawisko to, po okresie pewnego zahamowania wywołanego szokiem transformacji, przybrało wyraźnie na sile w połowie poprzedniej dekady, co miało wpływ na popyt mieszkaniowy na rynkach największych miast w Polsce.

Wśród czynników fundamentalnych oddziałujących na wzrost popytu na polskim rynku nieruchomości mieszkaniowych istotny wpływ miał również wzrost dostępności kredytów hipotecznych. Ciągły brak środków nie pozwalał w przeszłości uruchomić znaczących pod względem skali programów mieszkaniowych wspieranych środkami rządowymi. W tej sytuacji także samorządy lokalne, które są odpowiedzialne za sprawy mieszkaniowe na swoim obszarze, nie mogły udzielać odpowiedniego wsparcia na rzecz rozwoju budownictwa mieszkaniowego. Stąd też w sprzyjających warunkach ekonomicznych zasadniczym sposobem poprawy sytuacji mieszkaniowej polskich gospodarstw domowych było połączenie środków własnych z komercyjnym kredytem hipotecznym.

Z badań wynika, że szczególnie korzystne warunki makroekonomiczne dla rozwoju kredytowania hipotecznego powstały w Polsce, począwszy od 2005 roku (Główka, 2010, s. 83-85). Wówczas to wysokiemu wzrostowi gospodarczemu towarzyszyła bardzo niska inflacja i związany z nią niski poziom stóp procentowych. W tym okresie nie obserwowaliśmy zatem negatywnych zjawisk związanych zwykle z szybkim wzrostem PKB, takich jak silna presja inflacyjna. Poziom stóp procentowych w Polsce osiągnął w tym czasie tak niskie wartości, jakich nie notowano wcześniej. Jednocześnie w latach 2004-2008 obserwujemy spadek bezrobocia. Widoczna poprawa na rynku pracy zmniejszała poczucie zagrożenia utratą miejsc pracy, a systematyczna poprawa statusu materialnego wielu grup społecznych łączyła się z przekonaniem o jego dalszym wzroście w przyszłości. Ten powszechny optymizm miał swe podstawy nie tylko w przyśpieszonym rozwoju gospodarczym naszego kraju oraz licznych publikacjach prognozujących utrzymanie się tego trendu w długim okresie, ale był również w znaczącym stopniu wspomagany korzystną atmosferą 
związaną z przystąpieniem Polski do Unii Europejskiej. Zjawiska te miały istotny wpływ na podejmowane decyzje o wieloletnim zadłużaniu się polskich gospodarstw domowych na cele mieszkaniowe.

W tych uwarunkowaniach wartość kredytów hipotecznych wzrosła w Polsce w latach 2004-2008 blisko 7-krotnie (rys. 2). Miało to zasadniczy wpływ na popyt i tym samym poziom cen na rynku nieruchomości mieszkaniowych w Polsce.

Rysunek 2. Przyrost portfela kredytów hipotecznych w Polsce $(\mathrm{w} \%$, rok $2003=100)$

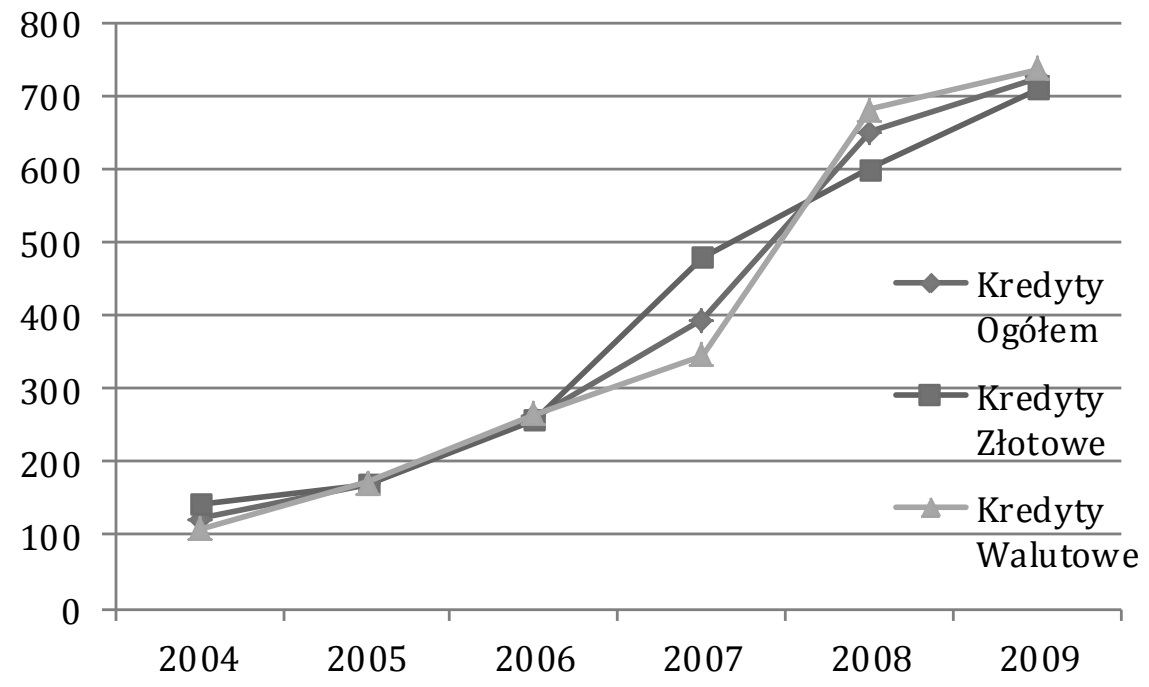

Źródło: opracowanie własne na podstawie danych AMRON.

Ponadto trzeba podkreślić, że istotny wpływ na szybki wzrost wartości udzielanych w Polsce kredytów hipotecznych miała także postępująca w tym okresie aprecjacja złotego oraz niski poziom stóp procentowych za granicą, w tym szczególnie w Szwajcarii. Sprzyjało to popularyzacji kredytów hipotecznych w walutach obcych. W całym okresie boomu kredytowania hipotecznego w Polsce stopy procentowe w franka szwajcarskiego były znacznie niższe niż w złotych. Tworzyło to, przy pozostałych bardzo korzystnych warunkach, trwałą podstawę wzrostu liczby i wartości zaciąganych mieszkaniowych kredytów denominowanych w walutach obcych, w tym głównie we frankach szwajcarskich. W tych uwarunkowaniach wpływ na poziom popytu na kredyty hipoteczne w Polsce realizowanej polityki banku centralnego w zakresie kształtowania stóp procentowych był ograniczony. Podwyżki 
stóp procentowych polskiego banku centralnego skutkowały wzrostem stóp procentowych - WIBOR dla kredytów złotowych, a większość kredytobiorców zaciągała zobowiązania denominowane w walutach obcych ze względu na niższy poziom stóp procentowych. Rosnące, począwszy od II kwartału 2007 roku do końca 2008 roku, stopy procentowe w Polsce w ograniczonej mierze hamowały popyt na mieszkaniowe kredyty hipoteczne, albowiem substytutem były tanie kredyty we frankach szwajcarskich. Udział kredytów w walutach obcych w portfelu kredytów hipotecznych wyniósł na koniec 2008 roku 66\% ogółem tego rodzaju kredytów znajdujących się w aktywach banków w Polsce.

Warto również zaznaczyć, że dodatkowym czynnikiem skłaniającym klientów do zainteresowania się kredytami w walutach obcych była polityka cenowa banków funkcjonujących na polskim rynku. Przy ogólnie obserwowanym zjawisku obniżania się średnich marż stosowanych przez banki przy udzielaniu kredytów hipotecznych mieliśmy do czynienia ze zjawiskiem bardzo podobnych tendencji dotyczących ich spadku od połowy 2005 roku, zarówno w przypadku kredytów w złotych, jak i we frankach szwajcarskich. Wcześniej polityka banków w tym zakresie była inna, a jej podstawową zasadą było, że marże w przypadku udzielanych kredytów w walutach obcych były z uwagi na wyższy poziom ryzyka znacznie wyższe.

Przedstawiony powyżej mechanizm rosnącej i niedostatecznie kontrolowanej przez władze publiczne dostępności mieszkaniowych kredytów hipotecznych, w tym szczególnie szeroki strumień kredytów denominowanych we frankach szwajcarskich, wywołał w Polsce boom kredytowy i w konsekwencji dynamiczny wzrost cen mieszkań. Kredyty hipoteczne były zasadniczym źródłem finansowania nieruchomości mieszkaniowych, a zmiany poziomu zadłużania się gospodarstw domowych były dobrym przybliżeniem zmian w popycie mieszkaniowym. Ze względu na to, że podaż mieszkań była wyraźnie mniej elastyczna od tak określanego popytu, doszło na polskim rynku nieruchomości mieszkaniowych do wzrostu cen. Niezwykle dynamiczny wzrost cen mieszkań, jaki wystąpił na tym rynku w badanym okresie, w sposób zdecydowany odbiegał od obserwowanego trendu długookresowego, co daje podstawy do zidentyfikowania zjawiska bańki cenowej (NBP, 2010).

$\mathrm{Z}$ powyższego wynika, że na pewnym etapie badanego cyklu koniunkturalnego na polskim rynku nieruchomości mieszkaniowych istotnymi uwarunkowaniami napędzającymi popyt i dalszy szybki wzrost cen mieszkań stają się czynniki pozafundamentalne o charakterze psychologiczno-spekulacyjnym. W rezultacie ich oddziaływania pojawiająca się presja nadwyżkowego popytu umożliwiała deweloperom sprzedaż również „wirtualnych”, czyli jeszcze niewybudowanych mieszkań 
w liczbie i cenie znacznie wyższej, niż to wynikało z fundamentalnej równowagi rynkowej. Na rynku deweloperskim obserwowaliśmy wówczas charakterystyczny dla boomu inwestycyjnego proces odkupywania terenów budowlanych przygotowanych do rozpoczęcia robót lub rozpoczętych już projektów mieszkaniowych.

Zauważalny wpływ na zjawisko dynamicznego wzrostu cen na rynku mieszkaniowym miała także kwestia postrzegania i wykorzystywania w coraz szerszym zakresie mieszkania jako dobra inwestycyjnego. Po wstąpieniu Polski do Unii Europejskiej ważnymi elementami determinującymi wzrost popytu inwestycyjnego i cen na rynku mieszkaniowym, który był finansowany łatwo dostępnymi kredytami hipotecznymi, były też czynniki o charakterze oszczędnościowo-spekulacyjnym. Do zasadniczych z nich można zaliczyć utrzymywanie się stóp zwrotu z inwestycji w nieruchomości mieszkaniowe na wyższym poziomie niż nominalne stopy procentowe od kredytów i depozytów, a także różnicę w cenach tego rodzaju nieruchomości w Polsce i innych krajach Unii Europejskiej oraz powszechne przekonanie o nieuchronności jej zmniejszania się w przyszłości. W tej sytuacji na rynku pojawiła się również pewna grupa klientów, zarówno krajowych, jak i z zagranicy, którzy przy wykorzystaniu kredytów hipotecznych kupowali mieszkania motywowani perspektywą wzrostu cen mieszkań, jaki miał miejsce wcześniej w wielu krajach Unii. Wielu inwestorów krajowych i zagranicznych nastawionych na spekulacyjne zakupy mieszkań oczekiwało powtórzenia się na polskim rynku nieruchomości mieszkaniowych w krótkim okresie tendencji podobnych do obserwowanych na rynkach zagranicznych. Doświadczenia płynące z polskiego rynku pokazały, że tego typu założenia były w znacznej mierze uzasadnione. Jeśli chodzi o inwestorów zagranicznych, to główną rolę na rynku odgrywali zwłaszcza ci z Irlandii i Hiszpanii, którzy na podstawie doświadczeń spekulacyjnych ze swoich rodzimych rynków podejmowali inwestycje na polskim rynku mieszkaniowym. Działo się to w atmosferze obawy przed dalszym wzrostem cen mieszkań, gdyż kierunki zmian tendencji rynkowych były wówczas dosyć trudne do przewidzenia. Zjawisko to dodatkowo przyczyniło się do nakręcenia spirali wzrostu cen mieszkań, oczekiwań cenowych i popytu.

W konkluzji można zatem powiedzieć, że na polskim rynku nieruchomości mieszkaniowych wystąpiły w badanym okresie liczne czynniki tworzące bańkę cenową. Jej pojawienie się oznaczało, że w sektorze nieruchomości mieszkaniowych mieliśmy do czynienia z tymczasowym stanem, który charakteryzował się tym, że rynkowa wycena mieszkań przestała mieć racjonalne uzasadnienie w czynnikach fundamentalnych, ale stała się w znacznej mierze wynikiem masowych i emocjonalnych zachowań. 
Pierwsze symptomy załamania się dynamiki wzrostu cen pojawiły się na polskim rynku mieszkaniowym w połowie 2008 roku. Zaczęła już wówczas spadać dostępność mieszkań z uwagi na poziom cen i zdolność kredytową, głównie dla tych nabywców, którzy planowali zaspokojenie własnych potrzeb bytowych. Były to pierwsze wyraźne oznaki spowolnienia na polskim rynku mieszkaniowym, a spektakularny upadek banku Lehman Brothers w III kwartale 2008 roku tylko przyśpieszył to zjawisko. Doszło wówczas do nałożenia się dwóch zasadniczych czynników. Po pierwsze, wyśrubowany poziom cen nieruchomości mieszkaniowych uruchomił naturalny mechanizm hamowania ich wzrostu. Dostępność mieszkań dla gospodarstw domowych stawała się coraz bardziej ograniczona, także wskutek niewystarczającego poziomu zdolności kredytowej. Ponadto banki w zaistniałej sytuacji kryzysowej dosyć nagle zaostrzyły politykę kredytową, co wywołało dodatkowy szok na rynku. Jak wynika z informacji NBP (2009) prawie wszystkie banki pod koniec 2008 roku sprzedające tego rodzaju kredyty znacznie zwiększyły marże, a dotyczyło to zarówno kredytów o normalnym, jak i podwyższonym profilu ryzyka. Zdecydowana większość banków zwiększyła też poziom wkładu własnego wymaganego przy finansowaniu nieruchomości mieszkaniowych. Blisko połowa z nich wyraźnie zwiększyła także pozaodsetkowe koszty kredytu hipotecznego. Ponadto wiele banków operujących na rynku mieszkaniowym skróciło maksymalny okres kredytowania i zaostrzyło warunki w zakresie zabezpieczeń, wymagając różnych form ubezpieczenia. Zaostrzenie polityki kredytowej dotyczących kredytów hipotecznych było znacznie większe dla kredytów we frankach szwajcarskich, a niektóre z banków całkowicie wstrzymały udzielanie kredytów hipotecznych w tej walucie.

Zahamowanie rosnącego dotąd popytu uruchomiło najpierw spowolnienie, a następnie spadek cen mieszkań. Cykl koniunkturalny na polskim rynku mieszkaniowym wszedł w fazę spadku. Faza dekoniunktury miała jednak w naszym kraju łagodny przebieg. Pomimo widocznego wpływu na polski rynek wydarzeń na rynkach zagranicznych i pewnej synchronizacji obserwowanych procesów dalszy przebieg fazy spadku miał już wyraźnie indywidualny charakter. Analiza tego zjawiska pokazuje, że sytuację na polskim rynku nieruchomości mieszkaniowych determinowały głównie czynniki krajowe. Pomimo że napięcia na tym rynku wystąpiły $\mathrm{z}$ widoczną siłą, to jednak nie przybrały zbyt szerokiej skali i nie wpłynęły w zasadniczy sposób na stan polskiej gospodarki. Stało się tak głównie dlatego, że nie doszło na naszym rynku do kumulacji niekorzystnych zjawisk, takich jak głęboki spadek cen nieruchomości mieszkaniowych, recesja w gospodarce, poważne osłabienie złotego i wreszczcie gwałtowne pogorszenie, co jest zwykle typowe w takiej sytu- 
acji, jakości bankowych aktywów hipotecznych. Wydaje się, że zasadniczy wpływ na taki przebieg cyklu na rynku nieruchomości mieszkaniowych w Polsce miały przede wszystkim takie czynniki, jak:

a) załamanie amerykańskiego rynku hipotecznego oraz pojawiające się podobne problemy na wielu rynkach europejskich, co o rok lub dwa skróciło okres dynamicznego wzrostu cen na polskim rynku mieszkaniowym;

b) ograniczony zakres popytu o chakterze spekulacyjnym na rynku nieruchomości mieszkaniowych w naszym kraju, a ponadto tego rodzaju zakupy mieszkań w przeważającej części okazały się inwestycjami długookresowymi, co w sumie nie zakłóciło łagodnego tempa zmian cen;

c) znacznie mniejsza skala finansowania sektora mieszkaniowego kredytem hipotecznych w Polsce, niż ma to miejsce na rynkach rozwiniętych;

d) niski poziom rozwoju polskiego system finansowania nieruchomości mieszkaniowych, co spowodowało, że instytucje finansowe nie były zaangażowane $\mathrm{w}$ operacje finansowe związane $\mathrm{z}$ bardzo ryzykownymi instrumentami emitowanymi na bazie kredytów hipotecznych.

\section{Zrównoważony stan polskiego rynku nieruchomości mieszkaniowych}

$\mathrm{Z}$ obserwacji sposobu funkcjonowania polskiego rynku mieszkaniowego wynika, że kryzys finansowy spowodował zamknięcie pierwszego w warunkach gospodarki rynkowej, zasadniczego etapu jego rozwoju. Procesy zachodzące na rynku nieruchomości mieszkaniowych w naszym kraju w ostatnich kilku latach można określić jako poszukiwanie nowego stanu jego równowagi. Obserwujemy na nim postępujące procesy dostosowawcze, które były rezultatem różnego rodzaju szoków z poprzedniego okresu.

Przy ciągle utrzymujących się na wysokim poziomie cenach mieszkań sytuacja na polskim rynku nieruchomości mieszkaniowych pozostaje w ostatnim czasie zrównoważona pomimo obserwowanej, począwszy od 2013 roku, powolnej próby jego wejścia $\mathrm{w}$ fazę ożywienia $\mathrm{w}$ nowym cyklu koniunkturalnym. $\mathrm{Z}$ informacji NBP (Łaszek, Augustyniak, Olszewski, Waszczuk, 2016) wynika, że ceny ofertowe i transakcyjne mieszkań na rynkach największych polskich miast wykazywały stabilizację z niewielką tendencją do ich wzrostu. Spadek stóp procentowych banku centralnego przekłada się na niższe stopy procentowe mieszkaniowych kredytów hipotecznych oraz depozytów, co powoduje wzrost popytu na rynku mieszkaniowym. 
W pewnym zakresie oddziałuje na ten proces również rządowy program MdM. Można powiedzieć zatem, że na rynku mieszkaniowym mamy do czynienia z pewną kumulacją pozytywnych stymulatorów popytowych zarówno fiskalnych, czyli MdM, jak i monetarnych w postaci niskich stóp procentowych.

W warunkach niskich stóp procentowych spada motywacja do gromadzenia oszczędności w bankach, a rośnie do zakupów mieszkań, wykorzystując w tym celu środki własne, kredyty bankowe oraz program MdM. Z raportu NBP wynika, że obserwujemy w ostatnich latach w naszym kraju wzrost zakupów mieszkań. Analiza struktury tych zakupów w dużych polskich miastach pokazuje, że ich podstawą są głównie mieszkania deweloperskie jedno- i dwupokojowe.

Istotnym stymulatorem przedstawionych zachowań nabywców mieszkań jest również to, że średnie stawki czynszu najmu mieszkań w dużych polskich miastach wykazują od pewnego czasu niewielki wzrost, a inwestycja polegająca na nabyciu mieszkania jest w obecnych uwarunkowaniach wyraźnie opłacalna. Jej rentowność jest wyższa niż lokaty bankowej i 10-letnich obligacji skarbowych. Natomiast relacja kosztów obsługi kredytu mieszkaniowego do czynszu najmu mieszkania umożliwia finansowanie obciążeń związanych z kredytem hipotecznym przychodami z najmu nieruchomości mieszkaniowych.

Trudno jednak prognozować, jak długo potrwa scharakteryzowany wyżej proces, gdyż rynek nieruchomości mieszkaniowych jest typowym rynkiem niedoskonałym, który w zdecydowanie większym stopniu kumuluje nierównowagi i wydłuża okres dostosowań, niż ma to miejsce na innych rynkach. Skomplikowanym zadaniem jest zatem przewidzieć, jakie skutki może przynieść nie tylko wysoka w ostatnim okresie liczba mieszkań oddawanych do użytku przez deweloperów, ale także liczba rozpoczynanych placów budów i uzyskiwanych pozwoleń na budowę. Cały czas bowiem produkcja mieszkań jest zyskowna i stopy zwrotu z projektów deweloperskich kształtują się na poziomie 15-20\%. Stąd też w branży deweloperskiej mamy do czynienia z wysoką koniunkturą, a ryzyko postrzegane jest jako niskie. Równocześnie jednak wyraźnie ograniczany jest ostatnio dostęp do kredytów hipotecznych pomimo niskich stóp procentowych. Banki zaostrzają kryteria ich udzielania, podnoszą marże kredytowe, a KNF zaleca im ostrożność i podnosi wymogi dotyczące LTV. Powstaje w tej sytuacji pytanie, w jaki sposób będzie kreowany popyt na rynku mieszkaniowym. 


\section{Podsumowanie}

Mechanizm funkcjonowania rynku nieruchomości mieszkaniowych, jak i doświadczenia historyczne płynące $\mathrm{z}$ wielu krajów wskazują na to, że jego cykliczności nie da się z pewnością w przyszłości uniknąć. Następujące po sobie okresy koniunktury i dekoniunktury wynikają z mechanizmu gospodarki rynkowej. Zasadniczym pytaniem jest natomiast to, czy można będzie skutecznie zapobiegać przekształcaniu się cykli na rynku mieszkaniowym w kryzysy destabilizujące gospodarkę. $\mathrm{Z}$ tego powodu pożądane wydaje się podejmowanie badań dotyczących czynników wpływających na amplitudę wahań, przede wszystkim cen, na rynku mieszkaniowym, ze szczególnym uwzględnieniem roli systemu finansowego, który dla przebiegu tego procesu ma kluczowe znaczenie. Obserwacje dotyczące przebiegu cykli na rynku nieruchomości mieszkaniowych pokazują, że jeżeli rynek ten nie jest nadmiernie i spekulacyjnie kredytowany, to jego wahania determinowane są głównie wzrastającą podażą i charakteryzują się w miarę łagodnym charakterem z umiarkowaną amplitudą wahań.

Wskazuje to na istotną rolę otoczenia makroekonomicznego i regulacyjnego w prawidłowym funkcjonowaniu systemu finansowania nieruchomości mieszkaniowych i stawia istotne wyzwanie dla działań instytucji publicznych w zakresie sposobu jego regulacji. Przez ostatnie kilkadziesiąt lat mieliśmy bowiem do czynienia z postępującym procesem deregulacji w tym obszarze. Chociaż niezwykle trudno jest określić, gdzie znajduje się optimum regulacji, to jednak skutki ostatniego kryzysu wskazują, że ta deregulacja okazała się zbyt głęboka. Z drugiej strony do kwestii regulacji należy podchodzić w sposób wyważony. Przeregulowanie systemu prowadziłoby do równie złych skutków, w tym przede wszystkim do zahamowania rozwoju rynku nieruchomości mieszkaniowych ze wszystkimi tego negatywnymi konsekwencjami.

\section{Literatura}

Deptuła, T. (2013). Rynek nieruchomości odrywa się od fundamentów. Rzeczpospolita Ekonomia, 17 października.

Foryś, I. (2014). Stan szczecińskiego rynku nieruchomości w latach dekoniunktury gospodarczej. Zeszyty Naukowe Uniwersytetu Szczecińskiego, 811, Studia i Prace Wydziatu Nauk Ekonomicznych i Zarzadzania, 36 (2), 211-224. 
Główka, G. (2010). Mieszkaniowy kredyt hipoteczny w Polsce. Warszawa: Oficyna Wydawnicza SGH.

Guttentag, J., Hering, R. (1984). Credit Rationing and Financial Disorder. Journal of Finance, 39 .

Kalicki, K., Krześniak, A. (2010). Stabilność międzynarodowych rynków aktywów finansowych. W: Stabilność międzynarodowych rynków finansowych. Warszawa: KGŚ, SGH.

Kindleberger, C.P. (1999). Szaleństwo, panika, krach. Teoria kryzysów finansowych. Warszawa: WIG Press.

Kucharska-Stasiak, E., Schneider, B., Załęczna, M. (2009). Methodology for Local and Regional Real Estate Markets. Analyses and Possible Applications of Results. Łódź: Wyd. UŁ.

Łaszek, J., Augustyniak, H., Olszewski, K., Waszczuk, J. (2016). Informacja o cenach mieszkań $i$ sytuacji na rynku nieruchomości mieszkaniowych $i$ komercyjnych $w$ Polsce w IV kwartale 2015 r. Warszawa: NBP.

Malpezzi, S., Wachter, S.M. (2004). The Role of Speculation in Real Estate Cycles. University of Pennsylvania.

NBP (2009). Sytuacja na rynku kredytowym - wyniki ankiety do przewodniczacych komitetów kredytowych - I kwartat 2009. Warszawa.

NBP (2010). Raport o sytuacji na rynku nieruchomości mieszkaniowych w Polsce w latach 2002-2009. Warszawa.

\title{
FINANCIAL DETERMINANTS OF PRICE BUBBLE ON THE POLISH HOUSING MARKET
}

\begin{abstract}
The phenomena of pricing bubble formation and burst on asset markets are a direct cause of disturbances in the stability of economies. Various pricing bubbles can be present on many types of markets; more and more often they concern also residential real estate markets. The article identifies factors which had the greatest impact on the process of pricing bubble formation and growth on the residential real estate market in the years 2004-2007. It shows, above all, detailed interrelations between the dynamics of price growth on the residential market and its financing system, and the impact of changing apartment prices in the years 2004-2015 on the operation of the real estate market and the banking sector in Poland.
\end{abstract}

\section{Translated by Gabriel Główka}

Keywords: residential market, business cycle, pricing bubble, financial system, mortgage loan, system stability

JEL Code: R31 
